\title{
PREVALENCE OF ROTAVIRUSES IN THE ETIOLOGY OF ACUTE DIARRHEA IN YOUNG CHILDREN, CLINICAL FORMS, EXTRAINTESTINAL MANIFESTATIONS AND COMPLICATIONS
}

\author{
Snezana Stojkovska, Irena Kondova-Topuzovska, Zvonko Milenkovikj, Mile Bosilkovski, \\ Krsto Grozdanovski, Maria Cvetanovska, Maria Dimzova, Sanja Petrusevska- Marinkovic, \\ Milena Stevanovikj, Ilir Demiri, Sunchica Bogoevska- Tasevska, Vesna Semenakova- Cvetkovska, \\ Valerija Kirova - Uroshevikj, Katerina Spasovska, Velimir Saveski \\ University Clinic of Infectious Diseases and Febrile Conditions Skopje, Medical Faculty, Skopje, RN Macedonia
}

Corresponding author: Prof. Dr. Snezana Stojkovska, University Clinic of Infectious Diseases and Febrile Conditions Skopje, Medical Faculty, Skopje, RN Macedonia

\section{ABSTRACT}

Rotavirus is highly contagious factor with dominant feces-oral transmission. Because it is stable in external environment, transmission clusters are possible by close contact, ingestion of contaminated water or food or contact with contaminated surfaces. It survives within hours and days on hands and contaminated surfaces. This makes it the most common enteric and nosocomial pathogen in the world, especially in early childhood. In addition to the rapid dehydration with pronounced electrolyte disturbances, numerous extraintestinal possibilities have been recorded in the clinical picture, which emphasizes the need for prevention of this disease.

In the period from 1.02.2018 to 31.01.2020 at the Clinic for Infectious diseases were treated 1060 patients with diarrheal disease, of which 502 children (47.36\%). Rotavirus etiology was confirmed in $23.30 \%$ of the children. According to the protocols, laboratory and biochemical investigations were done to all 117 children, with tracking parameters and their dynamics of admission and discharge from the hospital. Most of the children, $84(82.06 \%)$ are from urban areas, with a more confirmed epidemiological survey of 59 $(42.00 \%)$. The average age of the children was 8 months, with a small percentage of children on maternal food (breastfed 25, i.e. $21.37 \%$ ), with high febrile admission in $99 \%$ of children with an average temperature of $38.5 \mathrm{oC}$ and an average febrile duration of 4 days, with an average of $7(+2.49)$ of stools and 5 $(+2.12)$ of vomiting. There was a significant difference in hematocrit, leukocyte, electrolyte, glycaemia, and CRP values on admission and discharge. There was predominant isonatremic dehydration, and the compensatory mechanisms followed by the values of the electrolytes $\mathrm{ABS}, \mathrm{Ph}, \mathrm{BE}$ showed a tendency to maintain within the physiological limits. The clinical picture of extraintestinal manifestations included bronchitis, mesenteric lymphadenitis, upper respiratory infections and rash.

Rotavirus infection is a serious health and economic problem in our country, so it needs continuous prevention and monitoring in order to reduce the incidence, and thus the need for hospitalization and cure of rotavirus disease.

Keywords: frotavirus, incidence, clinical manifestations, prevention, immunization, complications 


\section{INTRODUCTION}

Viral gastroenteritis is caused by several viruses that replicate in the small intestine, and are most common in all age groups of Rota viruses. They mainly cause smaller or larger epidemiological calls of enterocolitis, often in cold winter months and are known as the cause of the, so-called, stomach flu. The highest frequency and the most serious clinical picture and complications occur in infants and young children [9].

As a result of the association of mortality and morbidity, it is a serious problem for the health system. By the age of five, virtually every child is infected with this pathogen, regardless of socioeconomic status. Global approximation is responsible for more than 111 million cases of pediatric gastroenteritis with 600,000 deaths per year. In underdeveloped countries, children are more prone to malnutrition and have more difficulty accessing medical care, which is why mortality is located there. In developed countries, it is due to its higher seasonal prevalence in the winter months correlated with the increased risk of its prevalence as a nosocomial pathogen. Equal prevalence of the virus in developed and underdeveloped countries suggests that the disease cannot be controlled by improving sanitation and hygiene. Vaccination is recognized as the only possible successful control measure in reducing severe forms of the disease [1], [2], [9].

Developing countries, where access to health care is limited, have the most severe consequences of the rotavirus disease, which in turn has a major impact on family, society, public health spending, and productivity of the population [14].

With this listing we have set a goal: to determine the prevalence of rotavirus in the etiology of acute diarrhea in young children, and to determine the clinical forms, extraintestinal manifestations and complications of the rotavirus disease, and, thus, to indicate the need for active prophylaxis and implementation of the vaccine in the National Program of Systemic Immunization of Children, and, therefore, its indirect impact will enable the reduction of the severe rotavirus disease globally [19], [20].

\section{MATERIAL AND METHODS}

In our study from 01.02.2018. to 31.01.2020, 117 children with confirmed rotavirus diarrhea were treated, which with its presentation of the severity of the disease required hospitalization and the children were hospitalized in the intestinal infections department at the Clinic for Infectious Diseases and Febrile Conditions.

The age of the children in the study was limited up to 14 years.

The diagnostic protocol with clinical follow-up, orientation laboratory follow-ups and specific diagnostic tests were performed.

To confirm the etiology, the following diagnostic tests were performed: immunochromatographic Rota/Adeno rapid test and PCR panel for enteral pathogens as well as mandatory microbiological follow-up.

According to the protocol, fecal leukocytes were made for each child, examination for possible presence of occult bleeding in the stool, as well as complete protocol for laboratory-chemical examination- complete blood count, $\mathrm{CRP}, \mathrm{Ph}$, electrolyte status with the values of $\mathrm{K}$ and $\mathrm{Na}$, urea, glucose, and ALT and AST values. Records were kept for each child of the number and quality of stools and vomiting.

Depending on the possible extraintestinal manifestations or complications, appropriate additional examinations were performed - abdominal echo, lumbar puncture and PCR of the cerebrospinal fluid, additional laboratory-biochemical analysis from dilated liver tests to cardiac enzymes and isoenzymes, ECG and others.

All clinical, laboratory and microbiological parameters - results were checked and statistically processed with STATISTIKA 8.0 and Statgraphics plus for windows 3.0.

\section{RESULTS}

In the period from 01.02.2018 to 31.01.2020, the Department for intestinal infections at the Clinic for Infectious Diseases and Febrile Conditions hospitalized 1060 patients with diarrheal syndrome, of which 502 were children ( $47.36 \%$ ).

Of all the children with diarrhea, the rotavirus etiology for diarrhea was confirmed by immunochromatographic Rota/Adeno rapid test of 117 $(23.30 \%)$ children, of which in $20(17.09 \%)$ it was confirmed by PCR panel for enteric pathogens.

In addition to the proven rotavirus infection in some children, the presence of another enteral 
pathogen was confirmed, as follows: Salmonella enteritidis - 1, Campilobacter jejuni - 1, Pseudomonas - 2, EAE Colli - 2, Noro virus - 2, Adeno virus -3 .

The average age of children with rotavirus diarrhea was 8 months $(\min =1 \mathrm{~m}$; $\max =41 \mathrm{~m}$; $\mathrm{sd}=9$ ). The prevalence by gender was: 44 female $(37.60 \%)$ and $73(62.40 \%)$ male. Only 25 children were breastfed $(21.37 \%)$. In terms of demo- graphic characteristics, the hospitalized children belonged to the central urban area, and only 21 $(17.94 \%)$ were from rural areas.

Laboratory biochemical parameters when admitting children to the hospital are shown in Table 1.

The clinical manifestations, extra intestinal manifestations and complications in patients with rotavirus diarrhea are shown in Table 2.

Table 1. Laboratory biochemical parameters when admitting children to hospital

\begin{tabular}{|c|c|c|c|c|c|}
\hline Parameter & normal value & mean & $\max$ & $\min$ & $\mathrm{SD} \pm$ \\
\hline $\mathrm{SE}$ & $<15$ & 13 & 60 & 2 & 12 \\
\hline $\mathrm{Hb}$ & $120-160$ & 121 & 172 & 81 & 17 \\
\hline $\mathrm{Er}$ & $4.20-5.50$ & 4.89 & 6.71 & 3.91 & 0.55 \\
\hline $\mathrm{Ht}$ & & 0.35 & 0.48 & 0.26 & 0.04 \\
\hline $\mathrm{Le}$ & $4-9$ & 11.18 & 45.10 & 2.00 & 6.16 \\
\hline $\mathrm{Ly}$ & $0.21-0.25$ & 0.30 & 0.75 & 0.01 & 0.20 \\
\hline $\mathrm{CRP}$ & $<6$ & 12.3 & 257.0 & 1.0 & 28.2 \\
\hline $\mathrm{Fe}$ & $6.60-32$ & 7.06 & 17.70 & 2.22 & 4.43 \\
\hline Urea & $1.70-8.30$ & 2.97 & 10.50 & 1.00 & 1.62 \\
\hline Glycaemia & $4.10-6.30$ & 4.12 & 7.20 & 1.00 & 0.99 \\
\hline $\mathrm{K}$ & $3.80-5.50$ & 4.00 & 5.80 & 2.50 & 0.70 \\
\hline $\mathrm{Na}$ & $135-145$ & 140 & 152 & 127 & 4 \\
\hline $\mathrm{ALT}$ & $9-43$ & 30.44 & 84 & 10 & 12.33 \\
\hline $\mathrm{AST}$ & $10-35$ & 44.21 & 81 & 18 & 12.46 \\
\hline $\mathrm{Ph}$ & $7.35-7.45$ & 7.35 & 7.49 & 7.19 & 0.06 \\
\hline $\mathrm{BE}$ & $1.5-3.0$ & -9.12 & 10.20 & -17.60 & 4.96 \\
\hline
\end{tabular}

Table 2. Clinical parameters, extra intestinal manifestations and complications

\begin{tabular}{cccccc}
\hline Parameter & normal value & mean & max & $\min$ & $\mathrm{SD} \pm$ \\
hospitalization & days & 6 & 16 & 3 & 2 \\
\hline $\mathrm{t}^{0} \mathrm{C}$ & $<37.00$ & 38.50 & 39.00 & 37.00 & 0.58 \\
$\mathrm{t}^{0} \mathrm{C}-$ before & days & 2 & 6 & 1 & 1 \\
$\mathrm{t}^{0} \mathrm{C}$ - after & days & 2 & 5 & 0 & 1.14 \\
\hline Stools & No/day & 7 & 10 & 5 & 2.49 \\
Vomits & No/day & 5 & 10 & 1 & 2.12 \\
\hline Parameter & No & $\%$ & & & \\
Fecal Le & 2 & 1.70 & & & \\
Benz. test & 5 & 4.27 & & & \\
\hline URT inf. & 6 & 5.12 & & & \\
Bronchitis & 6 & 5.12 & & & \\
Rash & 6 & 5.12 & & & \\
Mesenteric lymph. & 3 & 2.56 & & & \\
+ contact & 59 & 42.00 & & & \\
\hline
\end{tabular}


To reflect the severity of the clinical picture, the laboratory-biochemical parameters taken at admission and before discharge were monitored and their ratio is shown in Graphs 1, 2, 3, 4, 5, 6, 7 and 8 .

A Kolmogorov-Smirnov test was run to compare the distributions of the two samples. This test was performed by computing the maximum distance between the cumulative distributions of the two samples. Of particular interest is the approximate P-value for the test. Since the P-value is less than 0.05 , there is a statistically significant difference between the two distributions at the $95.0 \%$ confidence level.

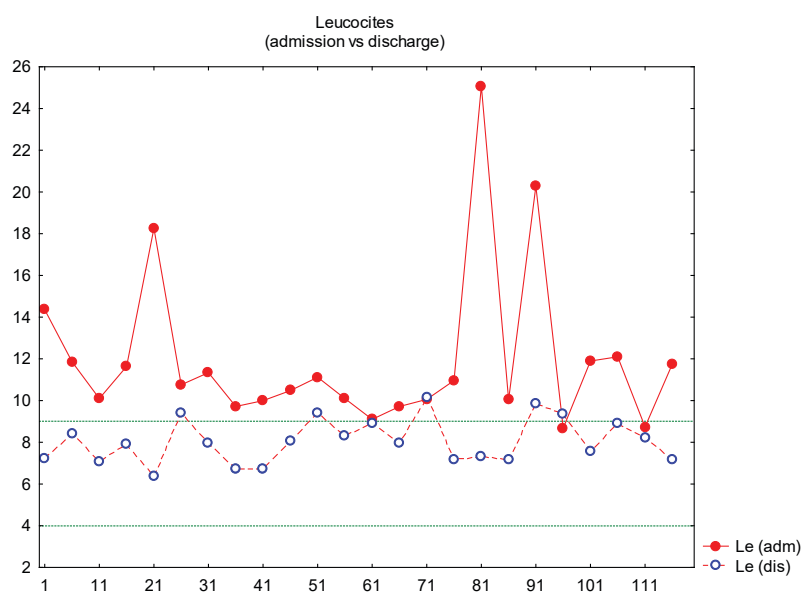

Graph 1. Distribution of individual values of Leucocytes at admission and discharge

It is shown that there are statistically significant differences between the two samples in admission and discharge.

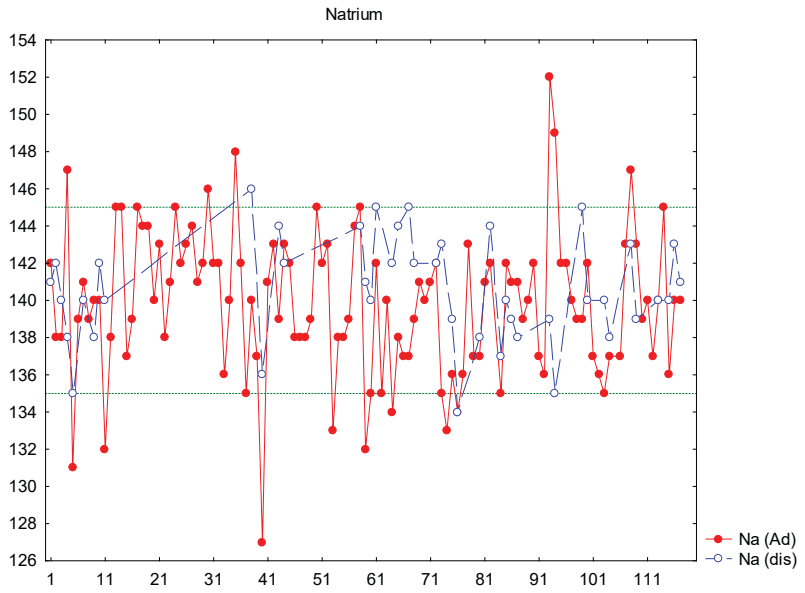

Graph 2. Distribution of individual values of $\mathrm{Na}$ at admission and discharge
Even though there are no statistically significant differences between the two samples in admission and discharge for both parameters Natrium and Potassium, it is obvious that departures from normal range for patients in admission were detected.

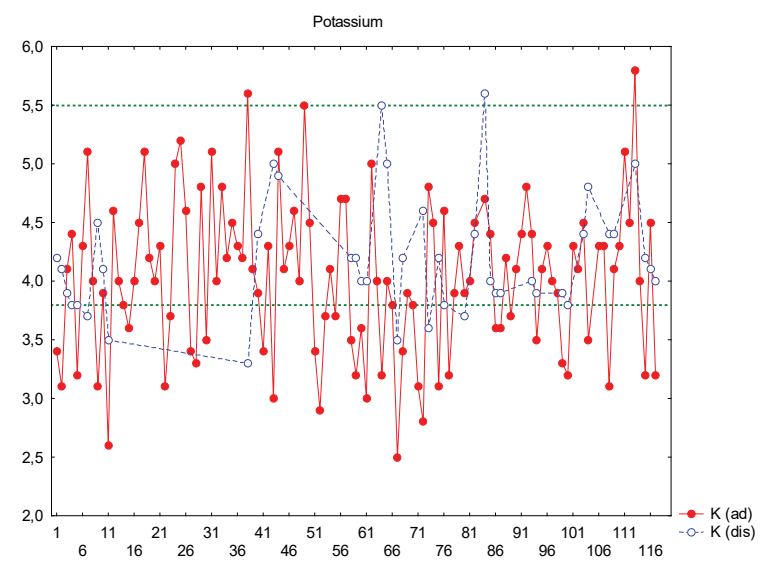

Graph 3. Distribution of individual values of $K$ at admission and discharge
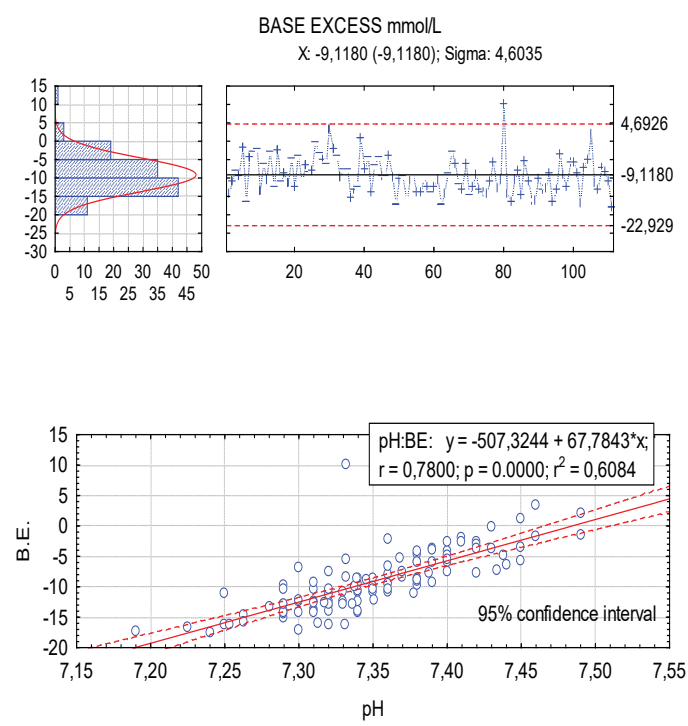

Graph 4. Distribution of individual values of BE at admission and relation of $B E v s p H$

In practical terms, it is stated with $95.0 \%$ of confidence that the true mean of BASE EXCESS is somewhere between -10.0507 and -8.18531, whereas the true standard deviation is somewhere between 4.3809 and 5.7131. While the confidence interval for the mean is quite robust and not very sensitive to violations of this assumption, the confidence interval for the standard deviation is quite sensitive.

The correlation coefficient $\mathrm{r}=0.78$ indicates a moderately strong linear relationship between 
BASE EXCESS and $\mathrm{pH}$ values. It can be used to construct prediction limits for new observations.

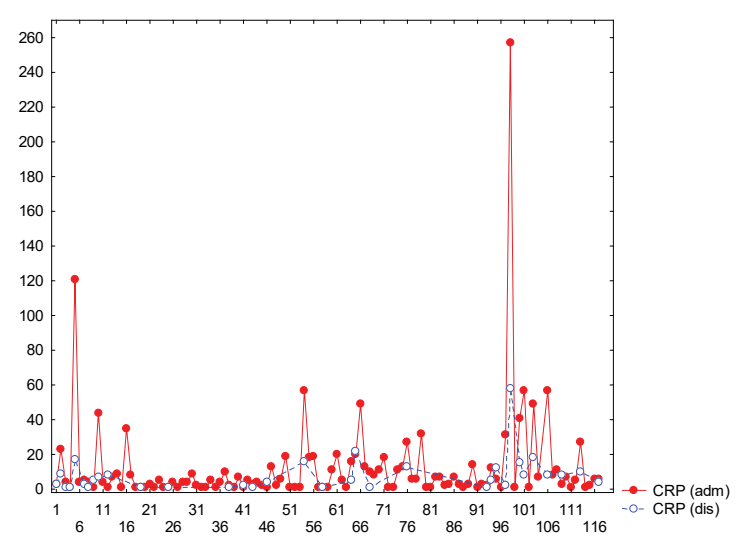

Graph 5. Distribution of values of CRP at admission and discharge

It is shown that there are statistically significant differences between the two samples for CRP, in admission and in discharge.

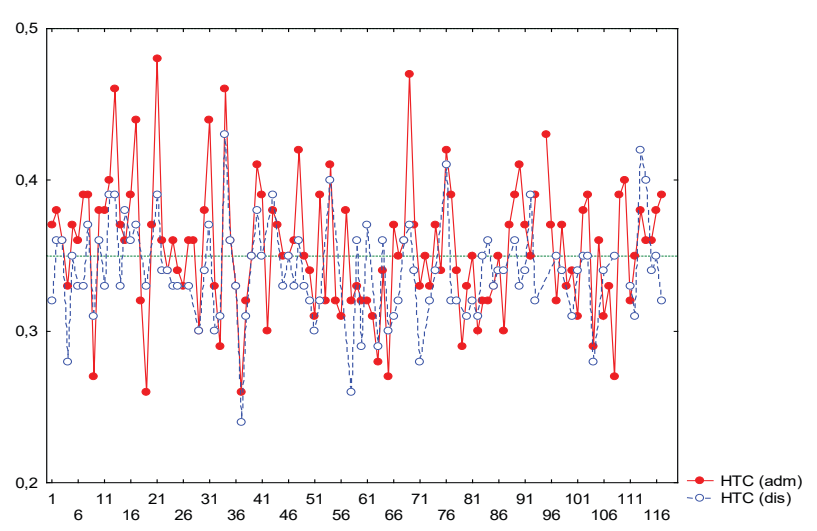

Graph 6. Distribution of values of Ht at admission and discharge

It is shown that there are statistically significant differences between the two samples for HEMATOCRIT, in admission and discharge, generally below the normal range.

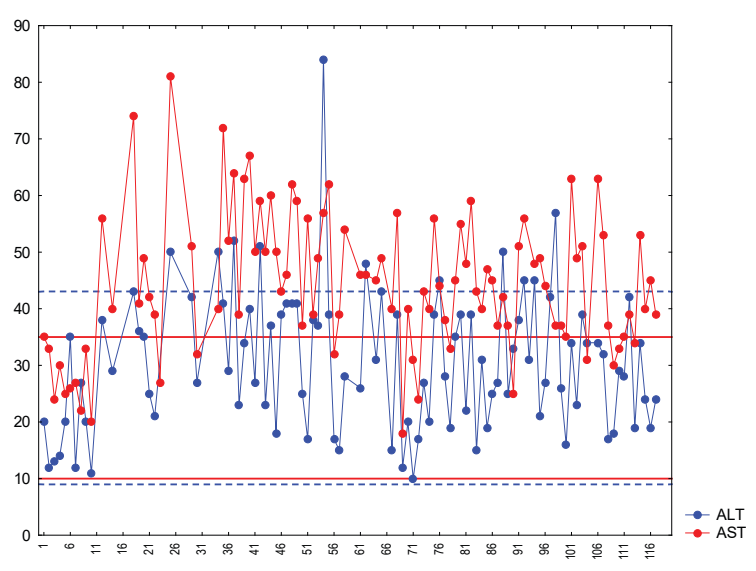

Graph 7. Distribution of values of ALT and AST at admission and discharge

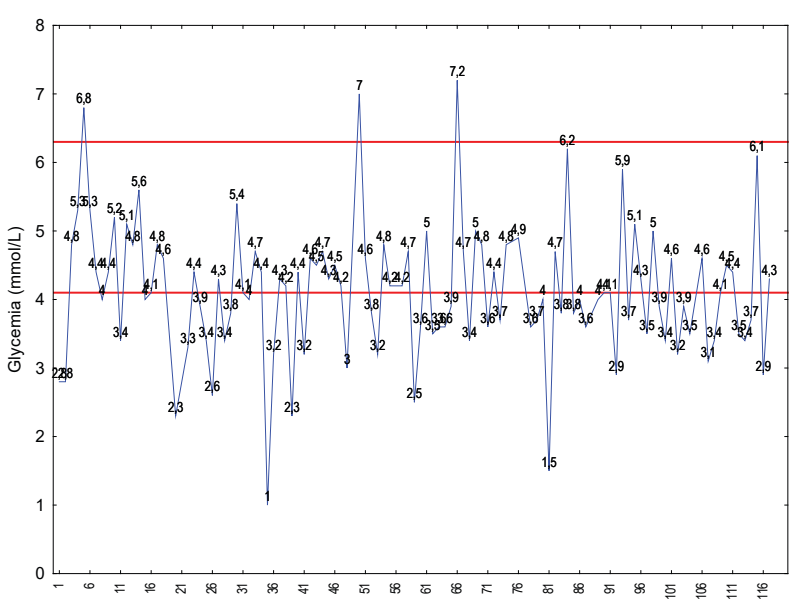

Graph 8. Distribution of values of glycaemia at admission and discharge

\section{DISCUSSION}

Rotaviruses have been the dominant pathogen in the etiology of diarrhea for almost 50 years, especially in infancy, as it stands out in all regions of the world and in developed and developing countries. A European rotavirus network has been 
organized by the EU to monitor the circulation of rotavirus, which covers 11 countries from which data are collected before and after the introduction of active prevention. Knowing all the features of the rotavirus disease - frequency, potential of severe clinical manifestations with lethal outcome due to extreme rapid dehydration, its escape from the intestine and the possibility of extraintestinal manifestations and complications, strong possible nosocomial pathogen, and no less, an important cost for the health system - it absolutely implies the need for the best treatment of the disease prevention [1], [2], [3], [4], [10].

In our study the rotavirus etiology has been proved at $23.30 \%$, which correlates with the data of studies in developing countries, unlike those in Belgium, Austria, Germany, where the proportion is significantly higher as explained by the collective concern for children in all types of preschool institutions [5], [6].

The dominant infant age is $\mathrm{x}=8$ months, which is characteristic of the rotavirus infection worldwide [15].

Whether the type of diet significantly affects the maturation of the local intestinal immunity - is of particular importance in our study, and despite the low age of the respondents, the natural diet in relation to breastfeeding is of a small percentage, only $21 \%$. This results in low serum iron levels and the development of a more severe clinical picture [7], [8], [16], [17].

Regarding the clinical picture at the admission, almost all children were febrile $(x=38.50 \mathrm{C})$ with an average temperature of 4 days. The predominant symptoms of vomiting and loose stools are expressed on admission with an average of 7 stools/24 hours and 5 vomits/24 hours. The relatively poor nutritional status, high fever and numerous stools and vomiting, as well as the positive epidemiological survey of 59 children due to stay in another institution, hospital or kindergarten, imply a longer hospitalization of 6 days on average, which is significantly longer than in the developed European countries. High fever and numerous stools and vomiting result in a significant difference in hematocrit, Le, electrolyte, and glycemic values on admission and on discharge. There was also a significant difference in the values of Ly and CRP. Although it is a group of severely acute dehydrated young children, the body's compensatory mechanisms monitored especially by electrolyte, $\mathrm{ABS}, \mathrm{PH}$, and $\mathrm{BE}$ values show a tendency to maintain extreme physiological limits. It is noteworthy that isonatremic dehydration is predominant, but with a significant deviation of the electrolyte values from the reference values of the admission in relation to the same at discharge [11], [12], [19].

What has been observed in the last decade in the world, especially in Italy, Finland and other western countries, as well as in Japan, are extraintestinal manifestations within the rotavirus infection, which is why it has been called rotavirus disease ever since. From the numerous possible extraintestinal presentations of the rotavirus disease in our study, bronchitis, mesenteric lymphadenitis, upper respiratory infections and rash were noted [11], [13], [18].

\section{CONCLUSION}

The rotavirus infection, as the most common confirmed cause of diarrhea in infants and young children, with the development of a severe clinical picture, with dehydration and numerous disorders in laboratory biochemical parameters and possible complications and extraintestinal manifestations is a serious health and economic problem in our country. As it is a possible preventable disease with already established and introduced mandatory immunization, its continuous implementation is necessary to monitor its effects that would lead to a reduction in the incidence, and, thus, the need for hospitalization and treatment of the rotavirus disease patient.

\section{Acknowledgments}

The authors would like to express their sincere gratitude to Pharm Spec Miroslava Ilievska for the statistical analyses.

\section{REFERENCES}

1. Adlhoch C., M. Hoehne, M. Littmann, et al. Rotavirus vaccine effectiveness and case-control study on risk factors for breakthrough infections in Germany: 2010-2011 Pediatr Infect Dis J, 32 (2) (2013), e82-e89.

2. Bellido-BlascoJ.B., S. Sabater-Vidal, MdM Salvador-Ribera, et al. Rotavirus vaccination effectiveness: a case-case study in the EDICS project, Castellon (Spain) Vaccine, 30 (52) (2012), 7536-7540. 
3. Braeckman T, K. Van Herck, N. Meyer, et al. Effectiveness of rotavirus vaccination in prevention of hospital admissions for rotavirus gastroenteritis among young children in Belgium: case-control study BMJ, 345 (2012), e4752.

4. Buttery JP, Lambert SB, Grimwood K, Nissen MD, Field EJ, Macartney KK, et al. Reduction in rotavirus-associated acute gastroenteritis following introduction of rotavirus vaccine into Australia's National Childhood vaccine schedule. Pediatr Infect Dis J 2011 Jan; 30(1 Suppl): S25-9.

5. Castilla J, X. Beristain, V. Martinez-Artola, et al. Effectiveness of rotavirus vaccines in preventing cases and hospitalizations due to rotavirus gastroenteritis in Navarre: Spain Vaccine, 30 (3) (2012), 539-543.

6. Folorunso OS, Sebolai OM. Overview of the Development, Impacts, and Challenges of Live-Attenuated Oral Rotavirus Vaccines. Vaccines (Basel). 2020 Jun 27; 8(3): E341. doi: 10.3390/vaccines 8030341 .

7. Gervasi G, Capanna A, Mita V, Zaratti L, Franco E. Nosocomial rotavirus infection: An up to date evaluation of European studies.Hum Vaccin Immunother. 2016 Sep; 12(9):2413-8. doi: 10.1080/21645515.2016.1183858. Epub 2016 May 16.

8. Ghazanfar H, Naseem S, Ghazanfar A, Haq S. Rotavirus vaccine--a new hope.J Pak Med Assoc. 2014 Oct; 64(10): 1211-6.

9. Gleizes $\mathrm{O}$, Desselberger U, Tatochenko V,et al. Nosocomialrotavirus infection in European countries: a review of the epidemiology, severity, and economic burden of hospital-acquired rotavirus disease. Pediatr Infect Dis J 2006; 25: S12-21.

10. Hemming M, Huhti L, Räsänen S, Salminen M, Vesikari T. Rotavirus antigenemia in children is associated with more severe clinical manifestations of acute gastroenteritis. Pediatr Infect Dis J. 2014 Apr; 33(4): 366-71. doi: 10.1097/ INF.0000000000000118.

11. Karafillakis E, Hassounah S, Atchison C. Effectiveness and impact of rotavirus vaccines in $\mathrm{Eu}-$ rope, 2006-2014.Vaccine. 2015 Apr 27; 33(18): 2097-107. doi: 10.1016/j.vaccine.2015.03.016. Epub 2015 Mar 18.
12. Muhsen K, G. Chodick, S. Goren, V. Shalev, D. Cohen The uptake of rotavirus vaccine and its effectiveness in preventing acute gastroenteritis in the community Vaccine, 29 (1) (2010), 91-94.

13. Paulke-Korinek M, H. Kollaritsch, S.W. Aberle, et al. Sustained low hospitalization rates after four years of rotavirus mass vaccination in Austrian Vaccine, 31 (24) (2013), 2686-2691358.

14. Rheingans RD, Heylen J, Giaquinto C. Economics of rotavirus gastroenteritis and vaccination in Europe: what makes sense? Pediatr Infect Dis J 2006; 25: S48-55.

15. Rivero-Calle I, Gómez-Rial J, Martinón-Torres F. Systemic features of rotavirus infection. J Infect. 2016 Jul 5; 72 Suppl: S98-S105. doi: 10.1016/j. jinf.2016.04.029. Epub 2016 May 12.

16. Shaheen MNF. Rotavirus gastroenteritis among hospitalized children under 5 years of age in the Eastern Mediterranean Region: a review. East Mediterr Health J. 2019 Aug 19; 25(6): 422-430. doi: 10.26719/emhj.18.054.

17. Stojkovska $\mathrm{S}$ et al .Evaluation of a rotavirus acute gastroenteritis severity score in hospitalized children over a ten year period in a clinic of infectious diseases, Skopje, R. Macedonia; contributions Sec.Med.Sci., XXXIV 2, 2013.

18. Vesikari T, M. Uhari, M. Renko, et al. Impact and effectiveness of RotaTeq vaccine based on 3 years of surveillance following introduction of a rotavirus immunization program in Finland Pediatr Infect Dis J, 32 (12) (2013), 1365-1373.

19. Tissera MS, Cowley D, Bogdanovic-Sakran N, Hutton ML, Lyras D, Kirkwood CD, Buttery JP. Options for improving effectiveness of rotavirus vaccines in developing countries. Hum Vaccin Immunother. 2017 Apr 3; 13(4): 921-927. doi: 10.1080/21645515.2016.1252493. Epub 2016 Nov 11

20. Vlasova AN, Kandasamy S, Chattha KS, Rajashekara G, Saif LJ. Comparison of probiotic lactobacilli and bifidobacteria effects, immune responses and rotavirus vaccines and infection in different host species. Vet Immunol Immunopathol. 2016 Apr; 172: 72-84. doi: 10.1016/j.vetimm.2016.01.003. Epub 2016 Jan 14. 


\title{
Резиме
}

\section{ЗАСТАПЕНОСТ НА РОТАВИРУСИТЕ ВО ЕТИОЛОГИЈАТА \\ НА АКУТНИТЕ ДИАРЕИ КАЈ МАЛИТЕ ДЕЦА, КЛИНИЧКИ ФОРМИ, ЕКСТРАИНТЕСТИНАЛНИ МАНИФЕСТАЦИИ И КОМПЛИКАЦИИ}

\author{
Снежана Стојковска, Ирена Кондова- Топузовска, Звонко Миленковиќ, \\ Миле Босилковски, Крсто Гроздановски, Марија Цветановска, Марија Димзова, \\ Сања Петрушевска- Маринковиќ, Милена Стевановиќ, Илир Демири, \\ Сунчица Богоевска- Тасевска, Весна Семенакова -Цветковска, \\ Валерија Кирова- Урошевиќ, Катерина Спасовска, Велимир Савески
}

Универзитетска клиника за инфективни болести и фебрилни состојби, Скопје, Медицински факултет, Скопје Република Македонија

Ротавирусот е висококонтагинозен причинител со доминантен фекоорален пренос. Бидејќи е стабилен во надворешната средина, трансмисијата е можна со блиски контакти, ингестија на контаминирана вода или храна и контакти со контаминирани површини. Со часови опстојува на рацете, а со денови на контаминирани површини. Тоа го чини најзастапен ентерален и нозокоминален патоген во светот, пред сѐ во малата детска возраст. Освен брзата дехидратација со изразени електолитни нарушувања, евидентирани се и бројни екстраинтестинални можности во клиничката слика, што ја потенцира потребата од превенцијата на оваа болест.

Во периодот од 1.2.2018 год. до 31.1.2020 год. на Клиниката за инфективни болести лекувани се 1060 пациенти со дијареална болест, од кои 502 деца (47,36 \%). Кај 23,3 \% од децата потврдена е ротавирусна етиологија. Кај сите 117 деца, по протокол, направени се лабораториско-биохемиски истражувања со следење на параметрите и нивна динамика на прием и на отпуштање од болница. Најголем број од децата, 84 (82,06 \%) се од градска средина, со потврдена епидемиолошка анкета кај 59 (42\%). Просечната возраст на децата беше 8 месеци, со мал процент деца на мајчина исхрана (доени 25, односно 21,37 \%), со висока фебрилност на прием кај 99 \% од децата со средна вредност на температурата од $38,5{ }^{\circ} \mathrm{C}$ и просечно траење на фебрилноста од 4 дена, со средно $7(+2,49)$ столици и $5(+2,12)$ повраќања. Имаше сигнификантна разлика во вредностите на хематокритот, леукоцитите, електролитите, гликемијата и ЦРП при приемот и при исписот. Имаше доминантна изонатремиска дехидратација, а компензаторните механизми следени со вредностите на електролитите АБС, Пх, БЕ покажаа тенденција кон одржување во крајните физиолошки граници. Во клиничката слика од екстраинтестиналните манифестации забележани беа бронхити, мезентеријален лимфаденит, горнореспираторни инфекции и раш.

Ротавирусната инфекција е сериозен здравствен и економски проблем во нашата земја, па потребно е нејзино континуирано превенирање и следење за да се постигне намалување на инциденцата, а со тоа и потребата за хоспитализација и лекување на ротавирусната болест.

Клучни зборови: ротавирус, инциденца, клинички манифестации, превенција, имунизација, компликации 